Available online http://iurnalmahasiswa.uma.ac.id/index.php/arbiter

\title{
Pembebasan Bersyarat Bagi Narapidana Di Lembaga Pemasyarakatan Klas II B Lubuk Pakam
}

\section{Conditional Release For Prisoners at Class Ii B Lubuk Pakam Penitentiary}

\author{
Edward Pahala Situmorang1), Utary Maharany Barus ${ }^{2)}$ \& Isnaini 3)* \\ Program Pasca Sarjana, Magister Ilmu Hukum, Universitas Medan Area, Indonesia \\ Fakultas Hukum Universitas Sumatera Utara, Indonesia \\ Fakultas Hukum Universitas Medan Area, Indonesia
}

\begin{abstract}
Abstrak
Penelitian ini bertujuan untuk melihat pelaksanaan pidana penjara bagi narapidana dan bagaimana pelaksanaan pembebasan bersyarat bagi narapidana serta apa hambatan dan upaya dalam pelaksanaan pembebasan bersyarat bagi narapidana, Penelitian ini dilakukan di Lembaga Pemasyarakatan Klas II B Lubuk Pakam. Metode pendekatan yang digunakan dalam penelitian ini adalah yuridis normatif, yaitu pendekatan yang menekankan pada pencarianpencarian dan bahan kepustakaan. Pembebasan bersyarat adalah proses pembinaan narapidana di luar Lembaga Pemasyarakatan setelah menjalani sekurang-kurangnya $2 / 3$ masa pidananya dengan ketentuan $2 / 3$ masa pidana tersebut minimal 9 bulan. Hambatan yang terjadi dalam Pelaksanaan Pembebasan Bersyarat oleh Lembaga Pemasyarakatan Klas II B Lubuk Pakamadalah Pengetatan pembebasan bersyarat bagi narapidana terkait Peraturan Pemerintah Nomor 99 Tahun 2012 bertentangan dengan Undang-Undang Nomor 12 Tahun 1995 sebagaimana disebutkan bahwa setiap narapidana berhak mendapat perlakuan yang sama seperti halnya hak memperoleh pembebasan bersyarat.
\end{abstract}

Kata Kunci: Lembaga Pemasyarakatan, Narapidana, Pembebasan Bersyarat

\begin{abstract}
This study aims to look at the implementation of imprisonment for prisoners and how the implementation of parole for prisoners as well as what are the obstacles and efforts in the implementation of parole for prisoners. The method of approach used in this research is normative juridical, which is an approach that emphasizes searches and library materials. Conditional release is the process of fostering prisoners outside Penitentiary after undergoing at least 2/3 of his sentence with a stipulation of 2/3 of the criminal period of at least 9 months. Obstacles that occur in the Conditional Release by the Class II Correctional Institution B Lubuk Pakamadalah Tightening parole for prisoners related to Government Regulation Number 99 of 2012 contrary to Law Number 12 of 1995 as stated that each prisoner is entitled to the same treatment as the right to obtain parole.
\end{abstract}

Keywords: Penitentiary, Prisoners, Parole

How to Cite: Edward Pahala Situmorang, Utary Maharany Barus \& Isnaini (2019). Pembebasan Bersyarat Bagi Narapidana Di Lembaga Pemasyarakatan Klas II B Lubuk Pakam. ARBITER: Jurnal Ilmiah Magister Hukum, 1(1): 89-97,

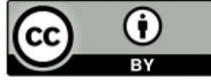




\section{PENDAHULUAN}

Hukum menetapkan apa yang harus dilakukan dan atau apa yang boleh serta yang dilarang. Sasaran hukum yang hendak dituju bukan saja orang yang nyata-nyata berbuat melawan hukum, melainkan juga perbuatan hukum yang mungkin akan terjadi, dan kepada alat perlengkapan negara untuk bertindak menurut hukum, sistem bekerjanya hukum yang demikian itu merupakan salah satu bentuk penegakan hukum.

Sejalan dengan perkembangan paradigma yang terus berubah di tengah-tengah masyarakat serta upaya penegakan hak asasi manusia dalam sistem tata peradilan pidana, maka dilakukan pembenahan serta perubahan-perubahan pada sistem kepenjaraan melalui payung hukum pemasyarakatan yaitu Undang-Undang Republik Indonesia Nomor 12 Tahun 1995 tentang Pemasyarakatan.

Untuk mengadopsi norma-norma hukum lama yang masih relevan maupun instrumen internasional, aspek sosial, maupun opini masyarakat. Perubahan paradigma sosial, budaya, ekonomi dan hukum dalam masyarakat merupakan hasil interaksi sosial pada tataran internasional yang dampaknya berimbas pada kondisi nasional, dampak tersebut cukup berpengaruh terhadap perkembangan sistem tata peradilan pidana di Indonesia termasuk sistem perlakuan terhadap warga binaan pemasyarakatan.

Lembaga Pemasyarakatan (Lapas) di mata masyarakat dipandang berfungsi sebagai tempat membatasi ruang gerak orang yang dijatuhi hukuman pidana penjara. Pembaharuan sistem pidana penjara secara lebih manusiawi dengan tidak melakukan perampasan hak-hak serta kemerdekaan warga binaan pemasyarakatan, melainkan hanya pembatasan kemerdekaan yang wajar sesuai dengan peraturan perundang-undangan yang berlaku dan norma-norma yang ada di masyarakat, merupakan dasar pertimbangan sistem pemasyarakatan yang bertujuan untuk mempersiapkan warga binaan pemasyarakatan agar dapat berintegrasi secara sehat dan bertanggung jawab di masyarakat.

Perlakuan terhadap warga binaan pemasyarakatan dengan sistem pembinaan pemasyarakatan disamping untuk mencegah diulangnya kejahatan serta perlindungan terhadap masyarakat, juga berupaya untuk mengintegrasikan warga binaan pemasyarakatan dalam derap langkah kehidupan masyarakat yang dinamis. Ditempatkannya warga binaan pemasyarakatan di masyarakat, diharapkan melalui pembinaan yang terus menerus akan tumbuh partisipasi masyarakat terhadap sistem pembinaan bagi warga binaan pemasyarakatan, yang sangat diperlukan bagi keberhasilan sistem pembinaan.

Pemasyarakatan Dalam PP No. 99 Tahun 2012 lebih memperketat syarat-syarat pemberian remisi, asimilasi dan pembebasan bersyarat bagi pelaku tindak pidana terorisme, narkotika dan prekursor narkotika, psikotropika, korupsi, kejahatan terhadap keamanan negara dan kejahatan hak asasi manusia yang berat, serta kejahatan transnasional terorganisasi lainnya untuk memenuhi rasa keadilan masyarakat.

Pemberian pembebasan bersyarat kepada narapidana yang melakukan tindak pidana korupsi mendapat pertentangan dari masyarakat luas. Pemberian pembebasan bersyarat ini seolah mematahkan usaha dan semangat bangsa ini untuk membangun memberantas tindak pidana korupsi. Tentu sangat tidak adil apabila koruptor yang telah 
mengakibatkan kerugian negara sebegitu besarnya dibebaskan dengan pemberian pembebasan bersyarat begitu saja. Pembebasan bersyarat ini juga berpotensi untuk tidak memberikan efek jera pada terpidana korupsi karena pembebasan bersyarat ini dapat menjadi jalan keluar untuk lari dari tanggung jawab atas kerugian negara akibat dari kejahatan korupsi yang telah mereka lakukan.

Lembaga Pemasyarakatan Klas II B Lubuk Pakam adalah salah satu UPT Pemasyarakatan Kementrian Hukum dan Hak Asasi Manusia Wilayah Sumatera Utara yang melaksanakan tugas pengamanan terhadap Warga Binaan Pemasyarakatan. Lembaga Pemasyarakatan Kelas II B Lubuk Pakam memiliki kapasitas hunian 350 orang, namun pada kenyataannya jumlah penghuninya adalah 1.239 orang. Masalah gangguan keamanan dan ketertiban di Lembaga Pemasyarakatan Kelas II B Lubuk Pakam dapat mempengaruhi keamanan di dalam Lapas. Berdasarkan uraian di atas maka penelitian tesis ini saya angkat dengan judul "Analisis Yuridis Pembebasan Bersyarat bagi Narapidana Lembaga Pemasyarakatan Klas II B Lubuk Pakam".

\section{METODE PENELITIAN}

Penelitian ini adalah penelitian hukum juridis normatif dan juga penelitian hukum empiris atau sosiologis, yaitu meneliti bahan-bahan kepustakaan yang berhubungan dengan pembinaan terhadap narapidana di Lembaga Pemasyarakatan Kelas II B Lubuk Pakam. Secara normatif dengan pelaksanaannya di lapangan mengenai pelaksanaan pembinaan terhadap narapidana dan menggambarkan, menelaah dan menjelaskan serta menganalisa ketentuan-ketentuan normatif dan praktek yang terjadi dalam lingkungan Lembaga Pemasyarakatan Kelas II B Lubuk Pakam. Penelitian yang dilakukan bertujuan untuk meneliti penerapan ketentuan-ketentuan perundang-undangan (hukum positif).

Pengumpulan data berkaitan dengan sumber daya karena melalui pengumpulan data akan diperoleh data yang diperlukan untuk selanjutnya dianalisis sesuai dengan yang diharapkan. Bahan hukum primer, bersumber dari badan hukum yang diperoleh langsung dan akan digunakan dalam penelitian yang merupakan bahan hukum yang mempunyai kekuatan mengikat secara yuridis yaitu: UUD 1945; KUHPidana; KUHPerdata; UndangUndang No. 12 Tahun 1995 tentang Pemasyarakatan, Peraturan Pemerintah Nomor 31 Tahun 1999 tentang Pembinaan dan Pembimbingan Warga Binaan Pemasyarakatan, serta peraturan perundang-undangan lainnya yang berkaitan dengan judul penelitian ini. Bahan hukum sekunder yang merupakan bahan hukum yang erat hubungannya dengan bahan hukum primer yang dapat membantu menganalisis serta memahami bahan-bahan primer yang terdiri dari : Buku-buku literature; Jurnal-jurnal hukum yang berkaitan dengan pendidikan; Makalah-makalah laporan penelitian; Artikel-artikel media masaa dan internet. Bahan hukum tersier, bahan hukum yang memberikan petunjuk atau penjelasan yang bermakna terhadap bahan hukum primer dan sekunder termasuk kamus dan lainlain.

Alat pengumpul data melalui studi dokumen dan literature yang berasal dari perpustakaan ataupun yang diperoleh dari lapangan yang berkaitan dengan Lembaga Pemasyarakatan Kelas II B Lubuk Pakam. Analisis data kualitatif normatif tanpa menggunakan angka-angka maupun rumusan statis. Analisis kualitatif menghasilkan data 
deskriptif, dilakukan reduksi atau pengolahan data, menghasilkan sajian data dan seterusnya diambil kesimpulan.

\section{HASIL DAN PEMBAHASAN}

\section{Tujuan Dilakukannya Pelaksanaan Pidana Penjara Bagi Narapidana}

Penjara ini diberi nama reformatory, yaitu tempat untuk memperbaiki orang, menjadikannya kembali menjadi seorang warga masyarakat yang berguna. Sistem penjara di Elmira pada prinsipnya pidana penjara dijalankan melalui tiga tingkatan, tetapi dengan titik berat yang lebih besar lagi pada usaha untuk memperbaiki si terhukum tersebut. Kepada si terhukum diberikan pengajaran, pendidikan dan pekerjaan yang bermanfaat bagi masyarakat.

Lamanya pidana penjara ditetapkan oleh pengadilan, akan tetapi Menteri Kehakiman diberi wewenang untuk melepaskan dengan perjanjian kepada si terhukum. Misalnya si terhukum dipidana selama tiga tahun, Menteri Kehakiman dapat mempunyai wewenang untuk melepaskan si terhukum apabila ia telah menjalani pidana selama enam bulan, dengan suatu perjanjian, yaitu selama masa sisa pidana yang belum dijalani oleh si terhukum tidak perlu dijalani akan tetapi si terhukum ditempatkan di bawah pengawasan khusus.

Selama masih di bawah pengawasan tersebut, masih terdapat kemungkinan si terhukum diwajibkan menjalani sisa pidana, apabila ternyata bahwa perjanjian yang menjadi syarat lepas tidak dipenuhi. Perbedaan antara sistem Elmira dengan Sistem Borstal, yaitu pada sistem Elmira pengadilan tidak lagi menetapkan lamanya pidana penjara yang bersangkutan, sedangkan dalam sistem Borstal pengadilan masih tetap menentukan lamanya pidana penjara yang bersangkutan. Akan tetapi di dalam praktek antara kedua sistem tersebut hasilnya sama.

Pidana pencabutan kemerdekaan yang terdiri dari pidana penjara dan pidana kurungan dilaksanakan di dalam penjara. Di antara para ahli hukum kebanyakan berpendapat bahwa pidana pencabutan kemerdekaan bukan berasal dari pandangan hidup borjuis liberalis-individualis. Adapun pelaksanaan Pembebasan bersyarat diberikan kepada narapidana yang telah menjalani 2/3 (dua per tiga) dari masa pidananya dan didasarkan kepada ketentuan dari Pasal 15a (1 s/d 6), Pasal 15b (1 s/d 3), Pasal 16 (1 s/d 4) dan Pasal 17 KUHPidana.

Pemberian pembebasan bersyarat bagi narapidana yang telah dilaksanakan selama ini selain tetap memperhatikan syarat yang tercantum dalam Pasal 15 KUHPidana, juga didasarkan kepada Surat Edaran Kepala Direktorat Jenderal Pemasyarakatan No. K.P. 10.15/3/1, tanggal 8 Pebruari 1965 dan Keputusan Dewan Pembina Pemasyarakatan. Ketentuan ini adalah era sebelum Undang-undang Pemasyarakatan diundangkan. Dengan adanya Undang-undang Nomor 15 Tahun 1995 maka semua ketentuan yang menyangkut pemasyarakatan narapidana mengacu kepada undang-undang tersebut.

Pelaksanaan pidana Penjara dengan sistem Pemasyarakatan di Indonesia saat ini mengacu kepada Undang-undang Nomor 12 Tahun 1995 tentang Pemasyarakatan. Penjelasan Umum Undang-undang Pemasyarakatan yang merupakan dasar yuridis filosofi tentang pelaksanaan sistem pemasyarakatan di Indonesia 
Narapidana bukan saja objek melainkan juga subjek yang tidak berbeda dari manusia lainnya yang sewaktu-waktu dapat melakukan kesalahan atau kekhilafan yang dapat dikenakan pidana, sehingga tidak harus diberantas. Yang harus diberantas adalah faktorfaktor yang dapat dikenakan pidana. Pemidanaan adalah upaya untuk menyadarkan Narapidana atau Anak Pidana agar menyesali perbuatannya, dan mengembalikannya menjadi warga masyarakat yang baik, taat kepada hukum, menjunjung tinggi nilai-nilai moral, sosial dan keagamaan, sehingga tercapai kehidupan masyarakat yang aman, tertib, dan damai.

Lembaga. pemasyarakatan sebagai ujung tombak pelaksanaan asas pengayoman merupakan tempat untuk mencapai tujuan tersebut di atas melalui pendidikan, rehabilitasi, dan reintegrasi. Sejalan dengan peran Lembaga Pemasyarakatan tersebut, maka tepatlah apabila Petugas Pemasyarakatan yang melaksanakan tugas pembinaan dan pengamanan Warga Binaan Pemasyarakatan dalam Undang-undang ini ditetapkan sebagai Pejabat Fungsional Penegak Hukum.

Sistem Pemasyarakatan di samping bertujuan untuk mengembalikan warga binaan pemasyarakatan sebagai warga yang baik juga bertujuan untuk melindungi masyarakat terhadap kemungkinan diulanginya tindak pidana oleh Warga Binaan Pemasyarakatan, serta merupakan penerapan dan bagian yang tak terpisahkan dari nilai-nilai yang terkandung dalam Pancasila.

Petugas pemasyarakatan merupakan Pejabat Fungsional Penegak Hukum yang melaksanakan tugas di bidang pembinaan, pengamanan, dan pembimbingan Warga Binaan Pemasyarakatan. Pejabat Fungsional diangkat dan diberhentikan oleh Menteri (Sekarang Menteri Hukum dan Hak Asasi Manusia) sesuai dengan peraturan perundangundangan yang berlaku.

Pemasyarakatan yang merupakan bagian akhir dari sistem pemidanaan dalam tata peradilan pidana adalah bagian integral dari tata peradilan terpadu (integrated criminal justice system). Dengan demikian, pemasyarakatan baik ditinjau dari sistem, kelembagaan, cara pembinaan, dan petugas pemasyarakatan, merupakan bagian yang tak terpisahkan dari satu rangkaian proses penegakan hukum.

Pelaksanaan pembebasan bersyarat bagi narapidana di lembaga pemasyarakatan kelas iib lubuk pakam Lembaga Pemasyarakatan Klas II B Lubuk Pakam merupakan salah satu Unit Pelaksanan Teknis Direktorat Jenderal Pemasyarakatan yang termasuk wilayah dari Kantor Wilayah Kementerian Hukum dan Hak Asasi Manusia Republik Indonesia Sumatera Utara. Lembaga Pemasyarakatan Klas II B Lubuk Pakam didirikan pada tahun 1928 diatas tanah dan bangunan seluas $16.550 \mathrm{~m}^{2}$ yang sebelumnya adalah Rumah Tahanan Negara (Rutan) Klas II B Lubuk Pakam. Rutan ini resmi menjadi Lembaga Pemasyarakatan (Lapas) pada tahun 1985.

Upaya penanggulangan terhadap kejahatan merupakan problematik yang klasik. Dengan kata lain, apakah terhadap kejahatan harus diberi sanksi? Jawabannya tentu saja ya, karena tidak seorang pun dibenarkan untuk menimbulkan kerugian pada orang lain atau menimbulkan keresahan umum dan gangguan terhadap ketertiban. Hukum pidana salah satunya berfungsi untuk menjaga ketertiban umum. Oleh karena itu, apabila ada seseorang yang menimbulkan ketidaktertiban umum harus diberi sanksi. Hukuman 
semata-mata dikaitkan dengan perbuatan masa lalu, tentang apa yang telah dilakukan seseorang, tidak berorientasi ke depan. Ketika itu berlaku apa yang disebut Andi Hamzah dan Siti Rahayu dengan utang patinyaur pati, utang lara nyaur lara, yang berarti si pembunuh harus dibunuh, si penganiaya harus dianiaya (hamzah \& rahayu, 1983)

Tujuan hukuman sebagai pembalasan telah ditinggalkan. Alasannya sebagaimana dikemukakan di atas bahwa pidana merupakan pencerminan peradaban sebuah bangsa. Menurut Beccaria sebagaimana dikutip oleh van Bemmelen bahwa kekejaman pemidanaan dapat dipakai sebagai ukuran tingkat kemajuan suatu bangsa.

Hakim tidak boleh menginterpretasi undang-undang untuk menjaga supaya kelaliman tidak muncul kembali. Pembuat undang-undang bertugas menetapkan apa yang diancam dengan pidana dalam bahasa yang dapat dimengerti dan seperlunya juga menghilangkan apa yang tidak jelas dalam undang-undang. Nam mengadili suatu kejahatan hakim harus menarik kesimpulan dari dua pertimbangan, yang pertama dibentuk oleh undang-undang dengan batas berlakunya dan yang kedua adalah berkaitan dengan pertanyaan apakah perbuatan konkret yang akan diadili itu bertentangan dengan undang-undang atau tidak? Putusan yang masuk akal adalah pembebasan atau pemidanaan. Apabila hakim diwajibkan menarik kesimpulan dari pertimbangan lain dari pada yang dua itu, atau jika hakim bertindak sendiri, maka kepastian hukum akan hilang.

Pemasyarakatan bukan hanya urusan Lembaga Pemasyarakatan sendiri. Dalam hal ini yang lebih berkepentingan, yaitu masyarakat sendiri mempunyai kepentingan jauh lebih besar, karena itulah tidak ada jeleknya, bahkan merupakan suatu keharusan untuk mengikutsertakan masyarakat. Kontak antara pegawai pemasyarakatan-narapidanamasyarakat, pasti akan menguntungkan semua pihak. Kesadaran kemasyarakatan, kesadaran untuk bertoleransi dan keamanan serta ketenteraman masyarakat pasti akan mengecap manfaat sebesar-besarnya dari kerja sama dan kontak itu.

Kepada narapidana dapat diberikan skill, yang kemudian dengan sekadar bekal, dapat mereka lanjutkan, walaupun sementara masih diawasi dan dibantu. Oleh sebab itu orang mengemukakan bahwa "pemasyarakatan dapat membantu swadaya dan swasembada dalam lapangan produksi.

Konsepsi tentang pemasyarakatan dapat disimpulkan bahwa gagasan pemasyarakatan adalah: narapidana harus dibimbing ke arah pengembaliannya ke dalam masyarakat sebagai seorang anggota masyarakat yang baik dan berguna sedangkan masyarakat harus disiapkan supaya menerima kembali narapidana ke dalam masyarakatnya itu, yaitu melahirkan kondisi-kondisi dalam masyarakat yang memungkinkan narapidana menjadi seorang anggota masyarakat yang baik dan berguna. Tujuan pidana terutama pemasyarakatan itu.

Hak-hak narapidana sebagaimana disebutkan diatas tercantum dalam Pasal 14 ayat (1) Undang-undang Nomor 12 Tahun 1995 tentang Pemasyarakatan. Setiap narapidana yang menginginkan haknya tersebut terpenuhi harus memenuhi syarat substantif dan administratif. Syarat tersebut diatur dalam Peraturan Pemerintah Nomor 99 Tahun 2012 tentang Perubahan Kedua Atas Peraturan Pemerintah Nomor 32 Tahun 1999 tentang Syarat dan Tata Cara Pelaksanaan Hak Warga Binaan Pemasyarakatan. Pada peraturan 
tersebut terdapat beberapa bentuk pengetatan syarat pemberian hak pada beberapa narapidana tindak pidana tertentu seperti terorisme, korupsi, dsb

Dari sudut hirarkhi perundang-undangan, PP No. 99 Tahun 2012 bertentangan dengan UU No 14 Tahun 1995 tentang Pemasyarakatan karena substansinya merupakan norma baru yang bertentangan dengan filosofi, tujuan dan misi UU Pemasyarakatan 1995 itu sendiri. Jika pun dikehendaki ada pembatasan, tidak dibenarkan bertentangan dengan Pasal 28 J UUD 1945 yang menegaskan bahwa pembatasan hak asasi hanya dapat dilakukan dengan undang-undang dan tidak boleh dengan peraturan perundangan di bawahnya.

UU Pemasyarakatan itu sendiri adalah perwujudan dan ratifikasi Kongres PBB tentang Pencegahan Kejahatan dan Perlakuan terhadap para pelanggar hukum (Tahun 1955). Konvensi tersebut belum ada Undang-Undang pelaksanaannya kecuali untuk Protokol Larangan Perdagangan Manusia sehingga ketentuan mengenai syarat justice collaborator (JC) dalam PP No. 99 Tahun 2012 khusus bagi narapidana korupsi dan bagi teroris serta narapidana narkoba terlalu dini dan tidak ada landasan hukum perundangannya. Selain itu, ketentuan Konvensi PBB tersebut di atas selalu merujuk pada prinsip hukum nasional dan konstitusi Negara peratifikasi sedangkan asas legalitas termasuk asas umum hukum pidana nasional sejak lama.

Hambatan dan upaya dalam pelaksanaan pembebasan bersyarat bagi narapidana. Dalam rangka pelaksanaan peraturan dalam UU Pemasyarakatan maka ditetapkanlah Peraturan Pemerintah yaitu Peraturan Pemerintah No. 32 Tahun 1999 tentang Pembinaan dan Pembimbingan Warga Binaan Pemasyarakatan. Selanjutnya PP No. 32 Tahun 1999 mengalami perubahan melalui Peraturan Pemerintah No. 28 Tahun 2006 tentang Perubahan Atas Peraturan Pemerintah No. 32 Tahun 1999 tentang Syarat dan Tata Cara Pelaksanaan Hak Warga Binaan Pemasyarakatan.

Peraturan Pemerintah dari UU Pemasyarakatan kembali mengalami perubahan yaitu melalui Peraturan Pemerintah No. 99 Tahun 2012 tentang Perubahan Kedua Atas Peraturan Pemerintah No. 32 Tahun 1999 tentang Syarat dan Tata Cara Pelaksanaan Hak Warga Binaan Pemasyarakatan. Pada PP No. 99 Tahun 2012 semakin memperketat syaratsyarat pembebasan bersyarat untuk narapidana tindak pidana khusus yang termasuk di dalamnya tindak pidana korupsi.

Dalam konsideran menimbang PP No. 99 Tahun 2012 disebutkan secara langsung tindak pidana korupsi sebagai salah satu tindak pidana luar biasa yang dalam pemberian hak-hak narapidananya (seperti hak untuk mendapatkan pembebasan) perlu diperketat lagi. Sehingga selain sebagai peraturan pelaksana dari UU Pemasyarakatan, PP No. 99 Tahun 2012 juga berkedudukan untuk mengatur lebih lanjut mengenai syarat-syarat dan tata cara pelaksanaan hak-hak narapidana yang diatur dalam UU Pemasyarakatan.

Peraturan Pemerintah No. 99 Tahun 2012 tentang Perubahan Kedua Atas Peraturan Pemerintah No. 32 Tahun 1999 tentang Syarat dan Tata Cara Pelaksanaan Hak Warga Binaan Pemasyarakatan tidak berlaku surut atau disebut dengan non-retroaktif. Asas nonretroaktif diatur dalam Pasal 28 Ayat (1) UUD 1945, melalui Pasal 14 Ayat (1) huruf k Undang-Undang No. 12 Tahun 1995 pembebasan bersyarat merupakan salah satu hak narapidana yang harus dihormati. Pembebasan besyarat atau disebut juga Pembebasan 
Bersyaratini tidak imperatif atau otomatis. Dikatakan "dapat" diberikan pembebasan bersyarat (Hamzah, 2012). Dalam ketentuan ini kata "dapat" menunjukkan bahwa pembebasan bersyarat mungkin saja tidak diberikan terhadap narapidana. Peraturan mengenai Pembebasan Bersyarat dalam PP No. 99 Tahun 2012 diatur dalam Pasal 43, Pasal 43A, dan Pasal 43B. Pasal 43 Ayat (2)

Pembebasan Bersyarat nantinya akan diberikan oleh Menteri setelah mendapatkan pertimbangan dari Direktur Jenderal Pemasyarkatan. Direktur Jenderal Pemasyarakatan sebelum memberikan hak narapidana ini harus meminta rekomendasi dari instansi terkait terlebih dahulu. Adapun hambatan dalam pelaksanaan Pembebasan bersyarat bagi narapidana antara lain: Khusus untuk tindak pidana terorisme, narkotika dan prekursor narkotika, psikotropika, korupsi, kejahatan terhadap keamanan negara dan kejahatan hak asasi manusia yang berat, serta kejahatan transnasional terorganisasi lainnya diberikan syarat tambahan seperti bersedia bekerja sama dengan penegak hukum untuk membantu membongkar perkara tindak pidana yang dilakukannya ( justice collaborator). Namun dalam pelaksanaannya tidak dibarengi dengan peraturan yang tegas mengenai format atau bentuk baku yang disepakati sehingga di lapangan sering terjadi penolakan dengan instansi terkait lainnya; Salah satu syarat tambahan lainnya untuk pembebasan bersyarat diwajibkan untuk mengikuti program asimilasi yang diatur dalam Permenkumham No 21 Tahun 2016 dengan bekerja sama dengan pihak ketiga melakukan kerja sosial di dalam lapas namun belum adanya aturan yang jelas dan bentuk baku kerja sama ini membuat banyak kalangan yang simpang siur dalam menafsirkannya sehingga sampai saat ini belum berjalan; Syarat tambahan untuk proses asimilasi bagi narapidana korupsi yaitu diwajibkan membayarkan denda sesuai bunyi putusan yang sangat memberatkan sehingga banyak narapidana yang tidak sanggup memenuhi persyaratan tersebut; Untuk narapidana teroris salah satu syarat tambahannya yaitu mengikuti kegiatan deradikalisasi namun kegiatan ini juga tidak berjalan maksimal.

Hambatan-hambatan diatas memang mempunyai tujuan yang baik agar memberikan efek jera kepada para pelaku tindak pidana tersebut. Namun tidak dibarengi dengan suatu peraturan yang tegas dalam pelaksanaannya, justru semakin mempersulit prosesnya membuat pembinaan narapidana tidak berjalan maksimalsehingga hampir seluruh LAPAS dan RUTAN seluruh Indonesia mengalami over kapasitas.

\section{SIMPULAN}

Lembaga Pemasyarakatan yang selanjutnya disebut LAPAS adalah tempat untuk melaksanakan pembinaan Narapidana dan Anak Didik Pemasyarakatan. Fungsi pemidanaan yang tadinya sebagai sistem pemenjaraan beralih menjadi sistem pemasyarakatan, karena narapidana tetap dianggap sebagai manusia yang tidak luput dari kesalahannya dan secara khusus tetap harus diberikan hak-haknya sebagai seorang narapidana selama menjalani pidananya. Sejalan dengan itu sesuai dengan Pasal 2 dan 3 Undang- undang No.12 Tahun 1995 tentang Pemasyarakatan. Sistem pemasyarakatan berfungsi menyiapkan Warga Binaan Pemasyarakatan agar dapat berintegrasi secara sehat dengan masyarakat, sehingga dapat berperan kembali sebagai anggota masyarakat yang bebas dan bertanggung jawab. Pembebasan bersyarat adalah proses pembinaan 
narapidana dan anak pidana di luar Lembaga Pemasyarakatan setelah menjalani sekurang-kurangnya $2 / 3$ (dua pertiga) masa pidananya minimal 9 (Sembilan) bulan.Setiap narapidana yang telah memenuhi syarat umum mempunyai hak untuk memperoleh pembebasan bersyarat yaitu telah menjalankan 2/3 masa pidananya. Pemberian Pembebasan Bersyarat bagi Narapidana yang dipidana karena melakukan tindak pidana diatur dalam Peraturan Pemerintah Nomor 99 Tahun 2012. Pemberian Pembebasan bersyarat sebagai salah satu hak narapidana yang diatur dalam Undangundang No.12 Tahun 1995 tentang Pemasyarakatan dimaksudkan agar narapidana di dalam menjalani pidananya memperoleh kesempatan untuk memperbaiki kesalahannya sehingga dapat diterima kembali di masyarakat mengalami banyak perubahan.

\section{DAFTAR PUSTAKA}

Hamzah, A. ( 2012). Asas-Asas Hukum Pidana di Indonesia \& Perkembangannya. Jakarta: Sofmedia.

Hamzah, A., \& Rahayu, S. (1983). Suatu Tinjauan Ringkas Sistem Pemidanaan Indonesia. Jakarta: Akademika Pressindo.

A. Josias Simon R. 2012. Budaya Penjara, Pemahaman, dan Implementasi. Bandung: Penerbit Karya Putra Darwati.

Abdul Ghafur Anshori (ed). 2008. Membangun Hukum Indonesia. Pidato Pengukuhan Guru Besar. Yogyakarta: Total Media.

Abintoro Prakoso. 2013. Kriminologi \& Hukum Pidana. Yogyakarta: Laksbang Grafika.

Andi Zainal Abidin Farid. 1987. Asas-Asas Hukum Pidana Bagian Pertama. Bandung: Alumni.

Arif Gosita. 1987. Relevansi Viktimologi dengan Pelayanan terhadap ParaKorban Perkosaan (Beberapa Catatan). Jakarta: Ind Hill-co.

Aruan Sakidjo dan Bambang Poernomo. 1990, Hukum Pidana, Dasar AturanUmum Hukum Pidana Kodifikasi. Jakarta: Ghalia Indonesia.

A. Widiada Gunakaya dan Petrus Irianto. 2012. Kebijakan Kriminal Penanggulangan Tindak Pidana Pendidikan, Bentuk Penerapan Sarana Non Penaldan Sarana Penal pada Pendidik dan Peserta Didik. Bandung: Alfabeta.

A.Z. Abidin dan Andi Hamzah. 2010. Pengantar dalam Hukum Pidana Indonesia.Jakarta: Yasrif Watampone. Bagir Manan. 2005. Sistem Peradilan Berwibawa (Suatu Pencarian). Yogyakarta: FH UII Pers.

Barda Nawawi Arief. 1994. Kebijakan Legislatif dalam Penanggulangan Kejahatan dengan Pidana Penjara. Edisi Kedua. Semarang: Badan PenerbitUniversitas Diponegoro.

Becker, Howard S. 1973. Outsiders, Study in the Sociology of Devieance. NewYork: The Free Press.

B. Marjono Reksodiputro. 1994. Hak Asasi Manusia dalam Sistem Peradilan Pidana. Kumpulan Karangan Buku Ketiga. Jakarta: Penerbit Pusat Pelayanan Keadilandan Pengabdian Hukum (d/h Lembaga Kriminologi Universitas Indonesia).

Andi Hamzah, Asas-Asas Hukum Pidana di Indonesia \& Perkembangannya, Sofmedia, Jakarta, 2012

Ermansjah Djaja, Meredesain Pengadilan Tindak Pidana Korupsi, Sinar Grafika, Jakarta, 2010

IGM Nurdjana, Sistem Hukum Pidana dan Bahaya Laten Korupsi, Pustaka Pelajar, Yogyakarta, 2010

Undang-Undang Nomor 12 Tahun 1995 tentang Pemasyarakatan, Lembaran Negara Republik Indonesia Nomor 77 Tahun 1995, Tambahan Lembaran Negara Republik Indonesia Nomor 3614

Peraturan Pemerintah Nomor 99 Tahun 2012 tentang Perubahan Kedua Atas Peraturan Pemerintah Nomor 32 Tahun 1999 tentang Syarat dan Tata Cara Pelaksanaan Hak Warga Binaan Pemasyarakatan, Lembaran Negara Republik Indonesia Nomor 225 Tahun 2012, Tambahan Lembaran Negara Republik Indonesia Nomor 5359.

https://www.academia.edu/14476693/Naskah_Akademis_Perubahan_PP_99

https://indonesaya.wordpr \ess.com/tag/diskriminatif-dalam-implementasi-peraturan-pemerintah-ppnomor-99-tahun-2012/ 